\title{
Evaluation of Nosocomial Infections after ABO-Compatible and Incompatible Liver Transplantations
}

\author{
ABO Kan Grubu Uyumlu ve Uyumsuz Karaciğer Nakli Sonrası Görülen Hastane Kökenli \\ Enfeksiyonların Değerlendirilmesi
}

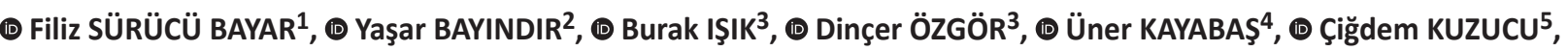 \\ (D) Sezai YILMAZ3 \\ ${ }^{1}$ Uşak Training and Research Hospital, Clinic of Infectious Diseases and Clinical Microbiology, Uşak, Turkey \\ 2inönü University Faculty of Medicine, Department of Infectious Diseases and Clinical Microbiology, Malatya, Turkey \\ 3inönü University Faculty of Medicine, Department of General Surgery, Liver Transplantation Institute, Malatya, Turkey \\ ${ }^{4}$ Ömer Halisdemir University Faculty of Medicine, Department of Infectious Diseases and Clinical Microbiology, Niğde, Turkey \\ SInönü University Faculty of Medicine, Department of Medical Microbiology, Malatya, Turkey
}

\section{Abstract}

Introduction: Liver transplantation is currently the only treatment option in acute hepatic failure and end-stage liver disease. In spite of their complications, ABO-incompatible liver transplantations are performed due to the shortage of suitable donors and the urgent need for organs. Despite developments in surgical techniques and improvements in antimicrobial prophylaxis strategies, infection is still an important complication and continues to be a major cause of death. In this study, $\mathrm{ABO}$-compatible and $\mathrm{ABO}$-incompatible liver transplant recipients were compared retrospectively in terms of infections and survival.

Materials and Methods: Sixteen ABO-incompatible liver transplant recipients whose transplant surgeries were performed by the Liver Transplant Team between March 2002 and January 2011 were included in the study. ABO-compatible liver transplant recipients whose surgeries were undergone before and after the $\mathrm{ABO}$-incompatible transplantation were selected as control group (total 32 patients). Patients' postoperative one year data were obtained from hospital records in both groups.

Results: In the first postoperative year after liver transplantation, 12 (75\%) of the ABO-incompatible recipients and 21 (65.6\%) of the ABOcompatible recipients experienced at least one infection attack $(p=0.509)$. The infection attack rate was $175 \%$ in the ABO-incompatible group and $113 \%$ in the $A B O$-compatible group ( $p=0.262)$. Eight (50\%) of the $16 \mathrm{ABO}$-incompatible recipients and nine (28.1\%) of the 32 ABO-compatible recipients died within one year of transplantation $(p=0.135)$. There were no statistically significant differences between the groups in terms of mortality or infection rates. Pseudomonas aeruginosa was the most common isolate in both $\mathrm{ABO}$-compatible and incompatible recipients.

Conclusion: The findings of the study showed that $\mathrm{ABO}$-incompatible transplants were comparable to $\mathrm{ABO}$-compatible transplants in terms of infection rates and survival. It should be kept in mind that $A B O$ incompatible liver transplantation may be an option, especially in emergencies and in selected cases, despite differences in complications between centers and patient groups and concerns about greater complications in ABOincompatible patients. However, further studies are needed on this topic.

Keywords: ABO-incompatible and compatible liver transplantation, infection, survival

\section{Öz}

Giriş: Günümüzde akut karaciğer yetmezliği ve son dönem karaciğer hastalığında tek tedavi seçeneği karaciğer naklidir. Uygun verici eksikliği ve acil organ gereksinimi sebebiyle ABO uyumsuz karaciğer nakilleri, komplikasyonları sık olmasına rağmen yapılmaya devam etmektedir. Cerrahi tekniklerdeki gelişmeler ve antimikrobiyal profilaksi stratejilerindeki ilerlemelere rağmen, enfeksiyonlar hala önemli bir komplikasyon olup, ölümlerin başlıca sebebi olmaya devam etmektedir. Bu çalışmada, merkezimizde yapılan ABO uyumlu ve uyumsuz karaciğer nakli alıcıları, enfeksiyonlar ve sağkalım yönünden retrospektif olarak incelendi.

Cite this article as: Bayar FS, Bayındır Y, Işık B, Özgör D, Kayabaş Ü, Kuzucu Ç, Yılmaz S. Evaluation of Nosocomial Infections after ABO-Compatible and Incompatible Liver Transplantations. Mediterr J Infect Microb Antimicrob. 2018;7:14.

Address for Correspondence/Yazıșma Adresi: Yaşar Bayındır MD, İnönü University Faculty of Medicine,

Department of Infectious Diseases and Clinical Microbiology, Malatya, Turkey

Phone: +90 4223411220 E-mail: yasarb44@hotmail.com ORCID ID: orcid.org/0000-0003-3930-774X

Received/Geliş Tarihi: 20.12.2017 Accepted/Kabul Tarihi: 14.04.2018

๑Copyright 2018 by the Infectious Diseases and Clinical Microbiology Specialty Society of Turkey

Mediterranean Journal of Infection, Microbes and Antimicrobials published by Galenos Yayinevi. 
Gereç ve Yöntem: Organ nakli ekibi tarafından, Mart 2002 ile Ocak 2011 arasında nakil yapılmış toplam 16 ABO uyumsuz karaciğer nakli alıcısı çalışmaya alındı. Kontrol grubu olarak ABO uyumsuz alıcılardan bir önce ve bir sonraki toplam 32 ABO uyumlu karaciğer alıcısı seçildi. Her iki hasta grubunun nakil sonrası bir yıllık süreye ait bilgilerine hasta kayıtlarından ulaşıldı.

Bulgular: Karaciğer nakli sonrası bir yıllık sürede, $A B 0$ uyumsuz hastaların 12'sinde (\%75), ABO uyumlu hastaların ise 21 'inde (\%65,6) en az bir enfeksiyon atağı saptandı ( $p=0,509)$. Enfeksiyon atak hızı $A B 0$ uyumsuz grupta \%175; $A B 0$ uyumlu gurupta ise \%113 olarak tespit edildi ( $p=0,262)$. Operasyon sonrası bir yıl içinde $A B 0$ uyumsuz hastaların sekizi $(\% 50)$; $A B 0$ uyumlu hastaların ise dokuzu $(\% 28,1)$ kaybedildi $(p=0,135)$. Her iki grupta mortalite ve enfeksiyon oranları yönünden fark saptanmadı. ABO uyumlu ve uyumsuz olan karaciğer nakil alıcılarında en sık izole edilen bakteri Pseudomonas aeruginosa idi.

Sonuç: Çalışmamız, enfeksiyon oranları ve sağkalım bakımından ABO uyumsuz nakillerin ABO uyumlularla benzer olduğunu göstermektedir. Merkezler ve hasta grupları arasında komplikasyonlar açısından farklılıklar olmasına ve uyumsuz hastalarda komplikasyonların daha fazla olacağı endişesine rağmen, özellikle acil durumlarda ve seçilmiş olgularda ABO uyumsuz karaciğer naklinin bir seçenek olabileceği akılda tutulmalıdır. Ancak, yine de bu konuda daha ileri çalışmalara gereksinim bulunmaktadır.

Anahtar Kelimeler: ABO uyumsuz ve uyumlu karaciğer nakli, enfeksiyon, sağkalım

\section{Introduction}

Liver transplantation is currently the most effective treatment method for primary and secondary liver cancers, metabolic diseases of the liver, and end-stage liver disease due to chronic or acute liver failure ${ }^{[1]}$. The lack of suitable donors as well as with patients who urgently need transplants in order to survive have led to transplantations from $A B O$-incompatible donors $^{[2]}$. ABO-incompatible liver transplantation continues to be a controversial issue due to the higher complication rates compared to $\mathrm{ABO}$-compatible transplantation ${ }^{[3]}$. Blood group antigens are not only present on the surface of blood cells, but also in the vascular endothelium and in the main bile ducts. The vascular endothelium and the biliary epithelium of hepatic allografts may continue to express donor blood group antigens for up to 150 days after transplantation. This makes ABO-incompatible grafts more susceptible to hepatic arterial thrombosis and immune-mediated bile duct injury ${ }^{[4]}$. These patients may die due to infections secondary to high dose immunosuppression or antibody-mediated rejection, hepatic necrosis, and intrahepatic biliary complications ${ }^{[3,5]}$.

Since liver is actually considered an immune tolerant organ, it is questioned if liver transplants from ABO-incompatible donors could be more successful than kidney and heart transplants or not. However, experience with ABO-incompatible liver transplantation in the 1980s and early 1990s showed that the postoperative course was extremely unfavorable and that severe rejection commonly led to refractory intrahepatic bile duct injury and hepatic arterial thrombosis ${ }^{[6]}$. It has also been reported that in such transplants, intensive immunosuppression and plasmapheresis have an adverse effect on outcomes and increase the incidence of sepsis ${ }^{[7]}$. However, some other studies have indicated that with recent improvements and developments, ABO-incompatible transplant outcomes have become comparable to those of $\mathrm{ABO}$-compatible liver transplantations ${ }^{[6]}$.

Despite developments in surgical techniques and advances in effective antimicrobial prophylaxis strategies, infection continues to be an important complication and major cause of death following transplantation ${ }^{[8,9]}$. Therefore, the aim of this study was to direct postoperative management strategies by determining whether infections in patients with $A B O-$ incompatible liver transplantation differ from those of patients with ABO-compatible transplantation or not.

\section{Materials and Methods}

A total of $17 \mathrm{ABO}$-incompatible liver recipients whose surgeries were performed by our Organ Transplant Team between March 2002 and January 2011 were evaluated retrospectively. The ABOcompatible liver recipients whose surgeries were undergone before and after each $\mathrm{ABO}$-incompatible patient were selected as the control group (total 34 patients). One $A B O$-incompatible liver recipient and two $\mathrm{ABO}$-compatible liver recipients were excluded from the analysis since they underwent a second transplant due to hepatic arterial thrombosis.

For both patient groups, data were extracted from Organ Transplant Clinic patient records, discharge summary reports, laboratory results, and Infectious Diseases and Clinical Microbiology consultation notes for a 1-year period after transplantation obtained from the hospital records system. Patients' demographic data, blood group, donor source (live or cadaver), liver failure etiology, length of preoperative and postoperative hospital stays, Model for End-Stage Liver Disease (MELD) score, infection attacks, and number of relaparotomies were recorded.

The standard antimicrobial prophylaxis protocol used was established by the Department of Infectious Diseases and Clinical Microbiology Organ Transplant Team based on our hospital 
and its organ transplant infection rates. Low-risk patients were administered intravenous ampicillin-sulbactam for 48 hours. High-risk patients (e.g. those undergoing reoperation, with fulminant hepatitis, preoperative stay in the hospital or intensive care unit, preoperative culture growth, massive hemorrhage, and massive transfusion) were administered piperacillin-tazobactam or a carbapenem, and vancomycin (if needed) for 48 hours. Intravenous fluconazole was administered for at least 14 days due to the increased risk of fungal infection in these patients. Starting on postoperative day 10, all patients received oral treatment consisting of co-trimoxazole 80/400 $\mathrm{mg} /$ day for six months and valganciclovir $900 \mathrm{mg} /$ day for 100 days. All patients received tacrolimus, mycophenolate mofetil, and prednisolone as routine immunosuppressive agents. ABOincompatible recipients received a standard immunosuppressive induction regimen with interleukin-2 receptor antagonists directly effective against leukocyte epitopes. In addition, the first nine patients underwent splenic artery ligation and the last seven patients underwent splenectomy.

Nosocomial infection attacks were classified according to the infection definitions determined by the Centers for Disease Control and Prevention ${ }^{[10]}$. Identification of the causative microorganisms and antibiotic susceptibility testing were done in accordance with the Clinical Laboratory Standards Institute guidelines ${ }^{[11,12]}$. Infections detected after organ transplantation were assessed as early (between 0-1 months), intermediate (between 1-6 months), and late infections (after 6 months) [9]. If cultures were positive for growth, culture antibotic susceptibility results were recorded. Infection attack rates were calculated using the following formula: (number of infection attacks/number of patients included in the study)x 100 .

\section{Statistical Analysis}

Statistical Package for the Social Sciences (SPSS) for Windows version 13 software was used for data analyses. Data pertaining to quantitative variables were expressed as mean \pm standard deviation and data pertaining to qualitative variables were expressed as numbers and percentages. Data pertaining to quantitative variables were analyzed using the Shapiro-Wilk test of normality. An unpaired t-test was used for normally distributed variables and Kruskal-Wallis, analysis of variance, and Mann-Whitney $U$ tests were used in analyses of variables that did not show a normal distribution. Pearson's chi-squared analysis and Fisher's exact test were used for qualitative variables. $\mathrm{P}$ values $<0.05$ were considered to be statistically significant.

\section{Results}

Of the $16 \mathrm{ABO}$-incompatible liver transplant recipients, 13 $(81.3 \%)$ were male and three $(18.8 \%)$ were female, and the mean age was $46.7 \pm 14.2$ (range: $17-63$ ) years. Of the $32 \mathrm{ABO}$ compatible liver transplant recipients in the control group, 24 $(75.0 \%)$ were male and $8(25.0 \%)$ were female, and the mean age was $45.9 \pm 11.9$ (age range: $20-71$ ) years. There was no statistical difference between the two groups in terms of age $(p=0.836)$ or $\operatorname{sex}(p=0.627)$ (Table 1$)$.

Ten (62.5\%) of the ABO-incompatible recipients had liver transplantation from a live donor and six $(37.5 \%)$ from a cadaver, while $30(93.7 \%)$ of the $\mathrm{ABO}$-compatible recipients had live donors and two $(6.3 \%)$ received organs from cadavers $(p=0.006)$.

When transplantations performed to $\mathrm{ABO}$-incompatible patients were analysed in terms of blood group, it was found that the most common liver transplant was from a blood type $A$ donor to a blood type 0 recipient (37.5\%).

Mean MELD scores were $22.4 \pm 5.5$ (range: $9-30$ ) in the ABOincompatible group and $18.0 \pm 6.8$ (range: $9-41$ ) in the $A B O$ compatible group. MELD scores were significantly higher among the $A B O$-incompatible liver transplant recipients $(p=0.029)$.

Eight (50\%) of the ABO-incompatible patients and 15 (46.9\%) of the $\mathrm{ABO}$-compatible patients underwent one or more relaparotomies for various indications in the post-transplant period. In both groups, a positive association was observed between the number of relaparotomies and number of infection attacks ( $p=0.014)$ (Table 2$)$.

Mean length of hospital stay was $12.9 \pm 9.5$ days preoperatively and $52.2 \pm 41.4$ days postoperatively for $\mathrm{ABO}$-incompatible recipients, and $9.1 \pm 11.8$ (1-60) days preoperatively and $47.1 \pm 35.5(9-141)$ days postoperatively for $\mathrm{ABO}$-compatible recipients ( $p=0.271$ preoperative, $p=0.656$ postoperative).

Table 1. Mean age and gender distribution of $A B O-$-compatible and $A B O$-incompatible liver transplant recipients

\begin{tabular}{l|c|c|c}
\hline & $\begin{array}{l}\text { ABO-incompatible } \\
\text { recipients }\end{array}$ & $\begin{array}{l}\text { ABO-compatible } \\
\text { recipients }\end{array}$ & $p$ value \\
\hline Mean age & $46.7 \pm 14.2$ & $45.9 \pm 11.9$ & 0.836 \\
\hline Sex & & & 0.627 \\
\hline Female $(n=11)$ & $3(18.8 \%)$ & $8(25.0 \%)$ & \\
\hline Male $(n=37)$ & $13(81.2 \%)$ & $24(75.0 \%)$ & \\
\hline
\end{tabular}

Table 2. The association between infection attacks and relaparotomy

\begin{tabular}{|c|c|}
\hline Number of relaparotomies & $\begin{array}{l}\text { Number of infection attacks } \\
\text { (mean } \pm \text { SD) }\end{array}$ \\
\hline 0 & $1.00 \pm 1.55^{*}$ \\
\hline 1 & $1.25 \pm 1.42^{*}$ \\
\hline 2 & $1.75 \pm 0.50^{*}$ \\
\hline$>2$ & $2.43 \pm 1.51^{*}$ \\
\hline
\end{tabular}


Mean survival time in the first year was $215.69 \pm 170.97$ (4-365) days for $A B 0$-incompatible patients versus $280.50 \pm 142.23$ (9-365) days for $A B O$-compatible patients $(p=0.171)$. Eight (50\%) of the $16 \mathrm{ABO}$-incompatible patients and 9 (28.1\%) of the $32 \mathrm{ABO}$-compatible patients died within the first year. There was no difference between the two groups in terms of 1 -year survival $(p=0.135)$. The mortality rates of both groups were higher in the early period (0-1 month), accounting for five deaths $(62.5 \%)$ in the $A B O$-incompatible group and five deaths (55.6\%) in the $\mathrm{ABO}$-compatible group. There was no difference between the groups in early mortality $(p=0.260)$.

Twenty-eight infection attacks were detected in 12 (75\%) of the $16 \mathrm{ABO}$-incompatible liver transplant recipients, and 36 infection attacks were detected in 21 (65.6\%) of the 32 ABOcompatible recipients $(p=0.509)$. Total infection attack rates were $175.0 \%$ in the $A B 0$-incompatible group and $113.0 \%$ in the $A B O$-compatible group ( $p=0.262$ ). It was found that $50 \%$ of infection attacks were in the intermediate period (1-6 months) in the ABO-incompatible patients, whereas $55.6 \%$ were in early period (0-1 month) in the $A B O$-compatible patients. No infection attacks occured in the $A B O$-compatible group after 6 months (Table 3).

Surgical site infections were the most common type of infection, occurring at a rate of $39.3 \%$ in the $\mathrm{ABO}$-incompatible group versus $47.2 \%$ in the $A B 0$-incompatible group (Table 4).

When infectious agents were evaluated, Pseudomonas aeruginosa was the most commonly isolated agent in both groups, accounting for seven (25.0\%) of all agents isolated in $\mathrm{ABO}$-incompatible recipients and $10(27.0 \%)$ of all agents isolated in $\mathrm{ABO}$-compatible recipients (Table 5).

Table 3. Numbers and rates of infection attacks in $A B O$-incompatible and $A B O$-compatible recipients after liver transplantation

\begin{tabular}{l|c|l|l|l|c|c|c}
\hline & \multicolumn{2}{|l|}{ ABO-incompatible } & \multicolumn{2}{l|}{ ABO-compatible } & ABO-incompatible & ABO-compatible & $p$ value \\
\hline Period & Number of infections & $\%$ & Number of infections & $\%$ & Infection rate (\%) & Infection rate (\%) & \\
\hline $0-1$ month & 12 & 42.9 & 20 & 55.6 & 75 & 63 & 0.884 \\
\hline $1-6$ months & 14 & 50.0 & 16 & 44.4 & 127 & 0.104 \\
\hline$>6$ months & 2 & 7.1 & 0 & 0.0 & 22 & 0 & 0.019 \\
\hline Total & 28 & 100 & 36 & 100 & 175 & 113 & 0.262 \\
\hline
\end{tabular}

Table 4. Distribution of infection attacks in $\mathrm{ABO}$-incompatible and $\mathrm{ABO}$-compatible recipients after liver transplantation

\begin{tabular}{l|r|r|r}
\hline & \multicolumn{1}{|l|}{$\begin{array}{l}\text { ABO-incompatible } \\
\mathbf{n}(\%)\end{array}$} & \multicolumn{2}{|l|}{$\begin{array}{l}\text { ABO-compatible } \\
\mathbf{n}(\%)\end{array}$} \\
\hline Surgical site infection & $11(39.3 \%)$ & $17(47.2 \%)$ & $28(43.8 \%)$ \\
\hline Bloodstream infection & $6(21.4 \%)$ & $10(27.8 \%)$ & $16(25.0 \%)$ \\
\hline Pneumonia & $8(28.6 \%)$ & $7(19.4 \%)$ & $15(23.4 \%)$ \\
\hline Urinary tract infection & $3(10.7 \%)$ & $2(5.6 \%)$ & $5(7.8 \%)$ \\
\hline Total & $28(100)$ & $36(100)$ & $64(100)$ \\
\hline
\end{tabular}

Table 5. Distribution of the agents isolated from $A B O$-incompatible and $A B O-$ compatible liver transplant recipients

\begin{tabular}{l|c|c|c}
\hline & ABO-incompatible & ABO-compatible & Total \\
\hline Agent & $\mathrm{n}(\%)$ & $\mathrm{n}(\%)$ & $\mathrm{n}(\%)$ \\
\hline Pseudomonas aeruginosa & $7(25.0)$ & $10(27.0)$ & $17(26.2)$ \\
\hline Enterococcus spp. & $5(17.8)$ & $2(5.4)$ & $7(10.8)$ \\
\hline Acinetobacter spp. & $4(14.3)$ & $6(16.2)$ & $10(15.4)$ \\
\hline Escherichia coli & $4(14.3)$ & $8(21.6)$ & $12(18.5)$ \\
\hline Klebsiella spp. & $3(10.7)$ & $4(10.8)$ & $7(10.8)$ \\
\hline Staphylococcus aureus & $1(3.6)$ & $2(5.4)$ & $3(4.6)$ \\
\hline Enterobacter spp. & $1(3.6)$ & $2(5.4)$ & $3(4.6)$ \\
\hline Stenotrophomonas maltophilia & $1(3.6)$ & $0(0.0)$ & $1(1.5)$ \\
\hline Candida spp. & $2(7.1)$ & $2(5.4)$ & $4(6.2)$ \\
\hline Burkholderia cepacia & $0(0.0)$ & $1(2.7)$ & $1(1.5)$ \\
\hline Total & $28(100)$ & $37(100)$ & $65(100)$ \\
\hline
\end{tabular}




\section{Discussion}

One of the main problems facing organ transplantation today is organ donor shortage $\mathrm{e}^{[13]}$. The discrepancy between the number of available organs and the number of patients waiting for liver transplantation, the increasing number of patients on transplant waiting lists, and the many patients who die while waiting in lists have become more conspicuous, especially over the past 10 years ${ }^{[14]}$.

As in many centers, there is also an organ donor shortage at our hospital, which enforces us to use of 'marginal donors'. The criteria for marginal liver donors are: obesity (weight $>100 \mathrm{~kg}$ or body mass index $>27$ ); age $>50$ years; macrovesicular steatosis $>50 \%$; intensive care unit stay $>4$ days; prolonged hypotensive attacks $>1$ hour and $<60 \mathrm{mmHg}$ with high inotropic drug use (dopamine $>14 \mu \mathrm{g} / \mathrm{kg} / \mathrm{min}$ ); cold ischemia time $>14$ hours; serum sodium value $>155 \mathrm{mEq} / \mathrm{L}$; sepsis, viral infections, and alcoholism; high bilirubin, alanine aminotransferase, and aspartate aminotransferase levels; and extrahepatic neoplasia ${ }^{[15]}$.

Although $\mathrm{ABO}$ compatibility between the recipient and donor is favored in liver transplants, $\mathrm{ABO}$-incompatible transplants are performed in cases of necessity, despite their many disadvantages ${ }^{[3,5]}$. During the study period, ABO blood group incompatible liver transplantation was performed on 16 patients for whom a suitable donor could not be found and who had acute or acute-on-chronic liver failure and needed urgent transplantation because they were at risk for grade 4 encephalopathy, coma, or death without immediate transplant. For this reason, this group had a higher proportion of cadaveric donors compared to the $\mathrm{ABO}$-compatible group. Live liver transplantation is superior to cadaver-sourced organs in terms of the quality of the graft parenchyma. In cadaveric liver transplants, there is the challenge of keeping the cadaver graft under hemodynamic control until the transplant procedure. Furthermore, there are uncertainties regarding the organ parenchyma (steatotic, ischemic), and there is also the risk of a probable emergency or uncontrolled procedure. Cadaver grafts wait longer in cold storage solutions, which adversely affects organ quality ${ }^{[16]}$.

In liver transplantation, graft and survival rates are considered to be direct indicators of transplant success. It is reported that most deaths occur between 1-6 months after liver transplantation ${ }^{[17]}$. In a retrospective study evaluating 234 liver transplants, 2-year graft survival rates were $30 \%$ among the $17 \mathrm{ABO}$-incompatible patients, 76\% among the 55 patients who underwent $A B 0-$ compatible emergency transplantation, and $80 \%$ among the 162 patients who were $\mathrm{ABO}$-compatible and underwent elective transplantation. In that study, humoral rejection, acute cellular rejection, arterial thrombosis, and biliary complications were higher in patients $\mathrm{ABO}$-incompatible than with $\mathrm{ABO}$-compatible patients. It was suggested that in addition to emergency transplant procedures and disease severity, $\mathrm{ABO}$ incompatibility was also an important cause of graft loss ${ }^{[7]}$. According to data from the European Organ Transplant Database, the risk of mortality is twice as high in $\mathrm{ABO}$-incompatible patients ${ }^{[18]}$. In a meta-analysis, it was determined that $\mathrm{ABO}$-incompatible liver transplant patients had lower survival rates than $A B O-$ compatible patients ${ }^{[19]}$. All of these problems mentioned above may attribute to the high infection rates and mortality. In the present study, the 1-year postoperative survival rates were lower in the $\mathrm{ABO}$-incompatible patients compared to the $\mathrm{ABO}$ compatible patients, but the difference was not statistically significant $(p=0.135)$. This was probably due to the small size of the control group and/or the characteristics of the patients.

Infections are the leading cause of death after solid organ transplantation. Approximately $80 \%$ of transplant recipients develop at least one major infection attack within the first year of organ transplantation ${ }^{[20]}$. In our study, 75\% of $A B O-$ incompatible patients and $65.6 \%$ of $\mathrm{ABO}$-compatible patients experienced at least one infection attack.

Although $\mathrm{ABO}$-incompatible patients were expected to have higher infection rates due to their higher MELD scores, there was no significant difference between the two groups, in our study. MELD score is generally used as an index of disease severity to predict survival rates in patients with end-stage liver disease, but it was later used to determine the priority of patients on cadaveric liver transplant waiting lists. However, its use for determining survival rates after liver transplantation is still controversial[ ${ }^{[21]}$. Although the mean MELD score of the ABO-compatible group seemed to be low in our study, there are several factors which may explain their high infection rate. There were patients in the group with MELD scores as high as 41 , with poor general condition, and extended stays in intensive care unit at the centers from which they were referred.

Liver transplant patients may require relaparotomy postoperatively due to complications such as bile leak, artery or biliary obstruction, venous thrombosis, or intraabdominal abscess. Studies have shown that relaparotomy increases the risk of infection ${ }^{[22,23]}$. Similarly, in the present study we observed a positive association between the number of relaparotomies and the number of infection attacks $(p=0.014)$. However, contrary to expectations, there was no difference between the two groups in terms of infection and mortality rates at the end of postoperative one year. This could be attributable to the high rate of relaparotomy in the $\mathrm{ABO}$-compatible group.

In our study, we evaluated infections occurring after liver transplantation in three periods: early (within 1 month), intermediate (1-6 months), and late (more than 6 months). In 
the $\mathrm{ABO}$-incompatible group, $42.9 \%$ of the infection attacks occurred in the early period, 50\% in the intermediate period, and $7.1 \%$ in the late period. In $\mathrm{ABO}$-compatible recipients, $55.6 \%$ of the total infection attacks occurred in the early period and $44.4 \%$ in the intermediate period, with no infection attacks detected in the late period. In previous studies, it is notable that incidences of post-transplant infection vary from center to center. Accordingly, infections are more common in the first month and decrease after six months ${ }^{[1,8,22]}$. In a study by Vera et al. ${ }^{[1]}$, there was a $37 \%$ infection rate in the first month and most of the bacterial infections occurred within the first month. In another study, Piselli et al. ${ }^{[24]}$ also determined that the incidence of infection among liver transplant recipients was particularly high in the early postoperative period, with $37.9 \%$ of the patients experiencing at least one infection attack within the first month. In our study, infection attacks were most common in the intermediate period among $\mathrm{ABO}$-incompatible patients and in the early period among $\mathrm{ABO}$-compatible patients.

Our results show that $39.3 \%$ of the total infection attacks among ABO-incompatible recipients were surgical site infections, 28.6\% were pneumonia, 21.4\% were bloodstream infections, and $10.7 \%$ were urinary tract infections in the 1-year period. Among the ABO-compatible recipients, $47.2 \%$ of all infection attacks were surgical site infections, $27.8 \%$ were bloodstream infections, $19.4 \%$ were pneumonia, and $5.6 \%$ were urinary tract infections. It is notable that surgical site infections were the most common infection type in both groups. The incidence of surgical site infections after liver transplantation is higher when compared to other solid organ transplants ${ }^{[25]}$. This may be explained by the complexity of the surgical procedures in liver transplantation, the fact that the operation takes place in the abdominal cavity, where the probability of contamination is high, and the unstable medical condition of many transplant recipients. In numerous studies, surgical site infections developed 2-3 weeks after organ transplantation ${ }^{[26,27]}$. The greatest risk factor for surgical site infection is choledochojejunal reconstructions ${ }^{[23]}$. An opening in the jejunum leads to surgical site contamination by enteric microorganisms and increases the risk of infection ${ }^{[26]}$. The preferred method of biliary tract reconstruction at our center is "duct-to-duct" anastomosis, and hepaticojejunostomy has been performed in patients with rare indications and biliary tract complications. Mycophenolate mofetil use is reported to be associated with surgical site infections in univariate analyses. In other studies, however, this treatment protocol did not increase the risk of bacterial infection. Mycophenolate mofetil is a potent immunosuppressive agent that inhibits $T$ and $B$ cell proliferation and is accepted as a risk factor for wound infections in solid organ transplants ${ }^{[28]}$. Tacrolimus, mycophenolate mofetil, and prednisolone were routinely used in our patients. Other important risk factors identified in studies are operative time and reoperation ${ }^{[29]}$.

Vera et al. ${ }^{[1]}$ reported that bloodstream infections were the most common (25.3\%) infection after liver transplantation, followed by urinary tract infections (15.7\%), liver and biliary tract infections (14.5\%), intraabdominal infections (10.8\%), surgical site infections (7.2\%), and lung infections (9.6\%). Bert et al. ${ }^{[30]}$ reported a total of 29.1\% blood tream infection during 1 year follow up in 704 liver transplant recipients.

The etiologic agents of common infections after liver transplantation usually change over time, and there may also be variations between countries and centers. For example, Chen et al. ${ }^{[31]}$ reported Escherichia coli as the most commonly isolated agent after liver transplantation, at a rate of 34\%, followed by Pseudomonas aeruginosa (26\%) and Staphylococcus aureus (8\%). In a study by Kim et al. ${ }^{[32]}$, intraabdominal infections were the most commonly detected infection after transplantation, at $37.6 \%$, followed by primary bacteremia in $17.4 \%$ and pneumonia in $14.5 \%$. They found that $39.9 \%$ of infections occurred in the first month and catheter-related coagulase-negative staphylococci were the most common agent. Another 31.1\% of the total infection attacks occurred in the intermediate period, with biliary tract infection due to Enterococcus spp. being the most common, while 29\% of the infection attacks occurred in the late period, with $E$. coli infections of the biliary tract being the most common. Evaluation of all agents isolated in our study shows that $P$. aeruginosa was isolated in $25 \%$ of ABO-incompatible recipients, followed by Acinetobacter spp. and $E$. coli at a rate of $14.3 \%$. In $\mathrm{ABO}$-compatible recipients, $P$. aeruginosa accounted for $27 \%$ of the isolated agents, $E$. coli for $21.6 \%$, and Acinetobacter spp. for 16.2\%.

The most common fungal infectious agents in liver transplant patients are Candida spp. ${ }^{[20]}$. In a study conducted by Shi et al. ${ }^{[33]}, 15.9 \%$ of the patients were diagnosed with fungal infections, of which $62.2 \%$ were Candida infections and 32.4\% were Aspergillus infections. In our study, Candida spp. were isolated in $7.1 \%$ of the $A B O$-incompatible recipients and $5.1 \%$ of the $\mathrm{ABO}$-compatible recipients. The low rate of Candida isolation among the patients included in our study is noteworthy. No fungal agents other than Candida were isolated in this study.

Limitations of this study include the small number of patients and the fact that the data set was not suitable for logistic regression analysis. Furthermore, autopsy could not be performed on the deceased patients.

\section{Conclusion}

In conclusion, organ donor and recipient characteristics, the hospital environment, antibacterial prophylaxis, regional 
epidemiology, and post-transplant management differ between centers. Therefore, each center should determine its post-transplant management strategy and establish its own protocols. Despite the concern that infections, antibodymediated rejection, and vascular and biliary complications would be common, our study revealed no statistically significant difference in infections developed in $\mathrm{ABO}$-incompatible liver transplant recipients versus in recipients $\mathrm{ABO}$-compatible donors. Though it is still a subject of debate, it may be more rational not to perform $\mathrm{ABO}$-incompatible liver transplantation unless there is an emergent necessity.

\section{Ethics}

Ethics Committee Approval: Retrospective study.

Informed Consent: Retrospective study.

Peer-review: Externally and internally peer-reviewed.

\section{Authorship Contributions}

Medical and/or Surgical and/or Diagnostic Practices: B.I., D.Ö., Ç.K., S.Y., Concept: F.S.B., Design: F.S.B., Y.B., Data Collection or Processing: Ü.K., Analysis or Interpretation: B.I., D.Ö., Literature Search: F.S.B., Ü.K., Writing: F.S.B., Y.B.

Conflict of Interest: No conflict of interest was declared by the authors.

Financial Disclosure: The authors declared that this study received no financial support.

\section{References}

1. Vera $A$, Contreras $F$, Guevara F. Incidence and risk factors for infections after liver transplant: single-center experience at the University Hospital Fundacion Santa Fe de Bogota, Colombia. Transpl Infect Dis. 2011;13:608-15.

2. Chui AK, Ling J, McCaughan GW, Painter D, Shun A, Dorney SF, Mears DC, Sheil AG. ABO blood group incompatibility in liver transplantation: a single centre experience. Aust N Z J Surg. 1997;67:275-8.

3. Troisi R, Noens L, Montalti R, Ricciardi S, Philippe J, Praet M, Conoscitore $\mathrm{P}$, Centra $\mathrm{M}$, de Hemptinne B. ABO-mismatch adult living donor liver transplantation using antigen-specific immunoadsorption and quadruple immunosuppression without splenectomy. Liver Transpl. 2006;12:1412-7.

4. Rummler S, Bauschke $A$, Baerthel $E$, Juette $H$, Maier K, Malessa C, Barz D, Settmacher U. ABO-Incompatible Living Donor Liver Transplantation in Focus of Antibody Rebound. Transfus Med Hemother. 2017;44:46-51.

5. Raut $\mathrm{V}$, Uemoto $\mathrm{S}$. Management of $\mathrm{ABO}$-incompatible living-donor liver transplantation: past and present trends. Surg Today. 2011;41:317-22.

6. Tanabe M, Kawachi S, Obara H, Shinoda M, Hibi T, Kitagawa Y, Wakabayashi G, Shimazu M, Kitajima M. Current progress in ABO-incompatible liver transplantation. Eur J Clin Invest. 2010; 40:943-9.

7. Gugenheim J, Samuel D, Reynes M, Bismuth H. Liver transplantation across ABO blood group barriers. Lancet. 1990;336:519-23.

8. Kusne S, Dummer JS, Singh N, Iwatsuki S, Makowka L, Esquivel C, Tzakis AG, Starzl TE, Ho M. Infections after liver transplantation. An analysis of 101 consecutive cases. Medicine (Baltimore). 1988;67:132-43.

9. del Pozo JL. Update and actual trends on bacterial infections following liver transplantation. World J Gastroenterol. 2008;14:4977-83.
10. Horan TC, Andrus M, Dudeck MA. CDC/NHSN surveillance definition of health care-associated infection and criteria for specific types of infections in the acute care setting. Am J Infect Control. 2008;36:309-32.

11. National Committee for Clinical Laboratory Standards: Performance Standards for Antimicrobial Susceptibility Testing. 11th. Informational Supplement M100-S11, 2001. NCCLS, Wayne.

12. Clinical and Laboratory Standards Institute. Performance Standards for Antimicrobial Susceptibility testing. Nineteenth Informational Supplement. CLSI Document M100-S19, 2009. CLSI, Wayne, PA.

13. Tector AJ, Mangus RS, Chestovich $P$, Vianna $R$, Fridell JA, Milgrom ML, Sanders C, Kwo PY. Use of extended criteria livers decreases wait time for liver transplantation without adversely impacting posttransplant survival. Ann Surg. 2006;244:439-50.

14. Nickkholgh A, Weitz J, Encke J, Sauer P, Mehrabi A, Buchler MW, Schmidt J, Schemmer P. Utilization of extended donor criteria in liver transplantation: a comprehensive review of the literature. Nephrol Dial Transplant. 2007;22 Suppl 8:viii29-viii36.

15. Tisone G1, Manzia TM, Zazza S, De Liguori Carino N, Ciceroni C, De Luca I, Toti L, Casciani CU. Marginal donors in liver transplantation. Transplant Proc. 2004;36:525-26.

16. Karademir S. Karaciğer transplantasyonu sonrası riskler ve enfeksiyonlar. In: Yalçın AN, Köse Ş., Erbay RH (ed). Transplant İnfeksiyonları. İstanbul: Can Matbaacılık, 2011:91-100.

17. Kim SI, Kim YJ, Jun YH, Wie SH, Kim YR, Choi JY, Yoon SK, Moon IS, Kim DG, Lee MD, Kang MW. Epidemiology and risk factors for bacteremia in 144 consecutive living-donor liver transplant recipients. Yonsei Med J. 2009;50:112-21.

18. Adam R, Cailliez V, Majno P, Karam V, McMaster P, Caine RY, O'Grady J, Pichlmayr R, Neuhaus P, Otte JB, Hoeckerstedt K, Bismuth H. Normalised intrinsic mortality risk in liver transplantation: European Liver Transplant Registry study. Lancet. 2000;356:621-7.

19. Wu J, Ye $S, X u X, X i e ~ H, Z$ hou L, Zheng S. Recipient outcomes after ABOincompatible liver transplantation: a systematic review and meta-analysis. PLoS One. 2011;6:e16521.

20. Romero FA, Razonable RR. Infections in liver transplant recipients. World J Hepatol. 2011;3:83-92.

21. Li C, Wen T, Yan L, Li B, Wang W, Xu M, Yang J, Wei Y. Does model for endstage liver disease score predict the short-term outcome of living donor liver transplantation? Transplant Proc. 2010;42:3620-3.

22. Snydman DR. Infection in solid organ transplantation. Transpl Infect Dis. 1999;1:21-8.

23. Patel $R$, Paya CV. Infections in solid-organ transplant recipients. Clin Microbiol Rev. 1997;10:86-124.

24. Piselli $P$, Zanfi $C$, Corazza $V$, Ferretti $S$, Scuderi $M$, Arana $M G$, Secchia $S B$, Lauro A, Dazzi A, Pinna A, Ettorre GM, Vennarecci G, Santoro R, Ferretti G, Gusman N, Berloco PB, Grossi P, Angeletti C, Bellelli S, Costa AN, Ippolito G, Girardi E, Serraino D. Incidence and timing of infections after liver transplant in Italy. Transplant Proc. 2007;39:1950-2.

25. Sanchez-Bueno $F$, Cuende N, Matesanz R, Parrilla P. Emergency organ transplantation in Spain: liver emergency and outcomes. Transplant Proc. 2005;37:3878-80.

26. Arnow PM, Zachary KC, Thistlethwaite JR, Thompson KD, Bova JL, Newell KA. Pathogenesis of early operative site infections after orthotopic liver transplantation. Transplantation. 1998;65:1500-3.

27. Asensio A, Ramos A, Cuervas-Mons V, Cordero E, Sanchez-Turrion V, Blanes M, Cervera C, Gavalda J, Aguado JM, Torre-Cisneros J, Red de Estudio de la Infeccion en el Trasplante - Grupo de Estudio de la Infeccion en el T. Effect of antibiotic prophylaxis on the risk of surgical site infection in orthotopic liver transplant. Liver Transpl. 2008;14:799-805. 
28. Bernabeu-Wittel $M$, Naranjo $M$, Cisneros JM, Canas $E$, Gentil MA, Algarra $G$, Pereira P, Gonzalez-Roncero FJ, de Alarcon A, Pachon J. Infections in renal transplant recipients receiving mycophenolate versus azathioprine-based immunosuppression. Eur J Clin Microbiol Infect Dis. 2002;21:173-80.

29. Winston DJ, Emmanouilides C, Busuttil RW. Infections in liver transplant recipients. Clin Infect Dis. 1995;21:1077-89; quiz 90-1.

30. Bert F, Larroque B, Paugam-Burtz C, Janny $S$, Durand F, Dondero F, Valla DC, Belghiti J, Moreau R, Nicolas-Chanoine MH. Microbial epidemiology and outcome of bloodstream infections in liver transplant recipients: an analysis of 259 episodes. Liver Transpl. 2010;16:393-401.
31. Chen TC, Lin $\mathrm{PC}$, Chi CY, Ho CM, Chou CH, Ho MW, Wang JH, Jeng LB. Infection in liver transplant recipients--analysis of 68 cases at teaching hospital in Taiwan. J Microbiol Immunol Infect. 2011;44:303-9.

32. Kim YJ, Kim SI, Wie SH, Kim YR, Hur JA, Choi JY, Yoon SK, Moon IS, Kim $\mathrm{DG}$, Lee MD, Kang MW. Infectious complications in living-donor liver transplant recipients: a 9-year single-center experience. Transpl Infect Dis. 2008;10:316-24.

33. Shi XJ, Lu SC, He L, Lu F, Liang YR, Luo Y, Ji WB, Zhao ZM. Diagnosis and treatment of fungal infection after liver transplantation. Chin Med J (Engl). 2011;124:1015-7. 